Sari Pediatri, Vol. 6, No. 1, Juni 2004: 40-46

\title{
Kelainan Kardiovaskular pada Sindrom Gawat Nafas Neonatus
}

\author{
Ramona Tobing
}

\begin{abstract}
Sindrom gawat napas neonatus(SGNN) atau respiratory distress syndrome (RDS) merupakan penyebab morbiditas utama pada anak. Sindrom ini paling banyak ditemukan pada BBLR terutama yang lahir pada masa gestasi $<28$ minggu. Penyebab terbanyak (SGNN) adalah penyakit membran hialin (PMH) yang terjadi akibat kekurangan surfaktan. Kelainan paru ini membawa akibat pada sistem kardiovaskular seperti terjadinya pengisian ventrikel kiri yang menurun, penurunan isi sekuncup, curah jantung yang menurun, bahkan dapat terjadi hipotensi sampai syok. Resistensi pembuluh darah paru yang meningkat dapat menimbulkan hipertensi pulmonal persisten. Pada bayi yang sembuh dari PMH dapat terjadi duktus arteriosus persisten (DAP). Pemeriksaan penunjang radiologis, laboratorium, EKG dan ekokardiografi sangat diperlukan untuk membantu menegakkan diagnosis RDS. Tata laksana penyakit ini sangat tergantung pada tingkat gangguan kardiovaskular yang terjadi.
\end{abstract}

Kata kunci: respiratory distress syndrome, penyakit membran hialin, sindrom gawat nafas neonatus.

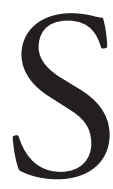

indrom gawat nafas neonatus merupakan suatu sindrom yang sering ditemukan pada neonatus dan menjadi penyebab morbiditas utama pada bayi berat lahir rendah (BBLR); ${ }^{1-12}$ sehingga SGNN disebut juga sebagai penyakit membran hialin (PMH) karena PMH merupakan bagian terbesar dari sindrom gawat nafas pada masa neonatus. ${ }^{1-11}$ Penyakit membran hialin umumnya terjadi pada bayi prematur. Angka kejadian PMH pada bayi yang lahir dengan masa gestasi 28 minggu sebesar $60 \%-80 \%$, pada usia kelahiran 30 minggu adalah 25\%, sedang pada usia kelahiran 32-36 minggu sebesar 15-30\%, dan pada bayi aterm jarang dijumpai. ${ }^{2-10}$ Di negara maju PMH terjadi pada $0,3-1 \%$ kelahiran hidup dan merupakan 15-20\% penyebab kematian neonatus. ${ }^{2,5}$ Di Amerika Serikat diperkirakan 1\% dari seluruh kelahiran hidup,

\footnotetext{
Alamat Korespondensi:

Dr. Ramona Tobing, SpA.

Kepala Subbagian Gizi. Bagian Ilmu Kesehatan Anak FK USU/RS HAM Jalan Bunga Lau No. 17

Telp. (061) 8361721, Fax. (061) 8361721 Medan
}

yang artinya 4000 bayi mati akibat SGNN setiap tahunnya. ${ }^{4,5}$ Di Indonesia, dari 950.000 BBLR yang lahir setiap tahun diperkirakan 150.000 bayi di antaranya menderita SGNN, dan sebagian besar berupa $\mathrm{PMH} .^{2}$

Penyakit membran hialin pada bayi kurang bulan (BKB) terjadi karena pematangan paru yang belum sempurna akibat kekurangan surfaktan. ${ }^{1-12,13,14}$ Tanpa surfaktan, alveoli menjadi kolaps pada akhir ekspirasi, sehingga menyebabkan gagal nafas pada neonatus. ${ }^{1-12}$ Pelbagai faktor ibu dan bayi berperan sebagai faktor risiko untuk terjadinya $\mathrm{PMH}$ pada $\mathrm{BKB}$ namun sebagian di antaranya masih kontroversial. ${ }^{1-4,5,7,10,12}$ PMH yang terjadi pada bayi kurang bulan tersebut bervariasi dari yang ringan sampai yang berat. Pada PMH ringan tidak memerlukan ventilasi mekanik sedangkan $\mathrm{PMH}$ berat memerlukan ventilasi mekanik. ${ }^{1-10}$ Semakin berat derajat $\mathrm{PMH}$, semakin berat keterlibatan kardiovaskular. ${ }^{2}$ Terapi optimal PMH menuntut teknologi canggih yakni pemberian ventilasi mekanik dengan atau tanpa pemberian surfaktan eksogen. ${ }^{1-10}$ Kelainan kardiovaskular pada 
PMH ringan belum terlalu banyak diteliti, sedang pada PMH berat kelainan kardiovaskular yang dijumpai antara lain disfungsi faal sistolik dan diastolik ventrikel kiri dan kanan, hipertensi pulmonal persisten, penurunan isi sekuncup dan curah jantung, bahkan bisa menyebabkan hipotensi sampai syok.$^{2-8,10}$ Kelainan kardiovaskular yang lain adalah gangguan faal jantung seperti penurunan pengisian ventrikel kiri, periode pra-ejeksi yang memanjang, dan waktu ejeksi yang memendek. ${ }^{2}$ Masalah kardiovaskular lain yang terjadi pada bayi yang sembuh dari PMH adalah terjadinya duktus arteriosus persisten (DAP)..$^{2-5,7,9}$ Dengan bertambahnya harapan hidup bayi berat lahir rendah, terlihat pula peningkatan jumlah bayi dengan DAP. ${ }^{1-5,7,9,10}$ Karena gangguan faal kardiovaskular pada SGNN berhubungan dengan proses pematangan paru, dalam hal ini defisiensi surfaktan, maka prognosis kelainan kardiovaskular pada PMH berkaitan erat dengan tingkat kelainan paru. ${ }^{1,2}$ Didapati penurunan kematian pada bayi dengan berat lahir 1500 gram dan masa kehamilan $>34$ minggu, bahkan tercatat tingkat kematian 0\% untuk bayi berat lahir 1500 gram dan $25 \%$ untuk bayi berat lahir lebih kecil. ${ }^{2}$ Memang perawatan intensif dapat menurunkan angka kematian, tetapi disisi lain dapat menambah kelainan neurologis dan kelainan perkembangan, baik mental maupun kognitif di masa depan, yang sulit diperbaiki. ${ }^{1,2,9}$

Tujuan dari tulisan ini adalah untuk memberikan uraian tentang gambaran kardiovaskular pada respiratory distress syndrome (sindrom gawat nafas neonatus)

\section{Gejala dan Tanda SGNN}

Gejala dan tanda klinis yang ditemui pada SGNN adalah: dispnu, merintih (grunting), takipnu (pernafasan lebih $60 \mathrm{x} /$ menit), retraksi dinding toraks dan sianosis. ${ }^{1-12}$ Gejala - gejala ini timbul dalam 24 jam pertama sesudah lahir dengan derajat yang berbeda, tetapi biasanya gambaran sindrom gawat nafas sudah nyata pada usia 4 jam. . $2,6,9,10$ Tanda yang hampir selalu didapat adalah dispnu yang akan diikuti dengan takipnu, pernafasan cuping hidung, retraksi dinding toraks, dan sianosis ${ }^{1-2}$ Diagnosis dini dapat ditegakkan bila telah ada gambaran sindrom tersebut, terlebih lagi bila disertai dengan adanya faktor-faktor risiko. ${ }^{10}$ Faktor - faktor risiko yang dapat kita pertimbangkan untuk meramalkan terjadinya SGNN adalah prematuritas, masa kehamilan, jenis kelamin, ras, riwayat kehamilan sebelumnya, bedah kaisar, diabetes, ketuban pecah lama, penyakit ibu. ${ }^{1-3,6,7}$

Gambaran radiologis kelainan paru pada $\mathrm{PMH}$ dibagi atas 4 derajat yaitu derajat 1 pola retikulogranular (PRG), derajat 2 bronkogram udara (BGU), derajat 3 sama dengan derajat 2 namun lebih berat dengan mediastinum melebar, derajat 4 kolaps seluruh paru sehingga paru tampak putih (white lung). 1-12 Pemeriksaan laboratorium yang dapat dilakukan yaitu pemeriksaan rasio L/S (lecithin sphingomyelin ratio) yang dilakukan pada air ketuban yang diperoleh dengan cara amniosentesis, atau dari aspirasi trakea dan lambung, dan deteksi fosfatidil gliserol yang menunjukkan kematangan paru. ${ }^{1,2,9,10}$

\section{Keterlibatan Kardiovaskular pada PMH}

Kekurangan surfaktan, baik oleh karena kurangnya produksi dan sekresi, adalah penyebab utama $\mathrm{PMH} .{ }^{1-}$ 12,13-19 Unsur utama dari surfaktan adalah lesitin, fosfotidilgliserol, apoprotein (surfaktan protein SPA,B,C,D), dan kolesterol. Dengan pertambahan usia kehamilan, bertambah pula jumlah sintesis fosfolipid dan disimpan di sel alveolar tipe II. Jumlah ini tidak mencukupi pada keadaan prematur. Surfaktan dalam konsentrasi tinggi didapatkan di dalam paru-paru fetus pada usia 20 minggu kehamilan. ${ }^{4,710}$ Tingkat kematangan surfaktan paru biasanya terlihat sesudah 35 minggu. ${ }^{7}$ Sintesis surfaktan bergantung dari $\mathrm{pH}$ yang normal, temperatur dan perfusi. Asfiksia, hipoksemia dan iskemia pulmonal terutama yang berhubungan dengan hipovolemia, hipotensi, stres dingin, bisa menekan sintesis surfaktan. Kekurangan sintesis atau pelepasan surfaktan menyebabkan atelektasis paru. Bergantung pada luas atelektasis, secara keseluruhan kelenturan paru menjadi berkurang seperlima sampai sepersepuluh nilai normal. Pada keadaan defisiensi surfaktan, paru bayi akan gagal mempertahankan fungsinya setelah bayi lahir dan juga gagal mempertahankan kestabilan alveolus pada akhir ekspirasi, sehingga pada saat inspirasi berikutnya dibutuhkan tekanan yang lebih besar untuk mengembangkan alveolus yang kolaps. Kelainan tadi menyebabkan terjadinya gangguan ventilasi dan perfusi dalam paru hingga timbul hipoksemia pada bayi. ${ }^{1-12,13-19}$

Pada pemeriksaan akan tampak bayi menderita dispnu dan hiperpnu dengan frekuensi pernafasan lebih dari $60 \mathrm{kali} /$ menit, sianosis karena saturasi $\mathrm{O}_{2}$ 
berkurang, dan terjadi apnu. ${ }^{1-12}$ Pada kasus yang berat, di sebagian besar (50\%-60\% ) area paru tidak terjadi perfusi yang akhirnya dapat menyebabkan hipoksia. Berkurangnya komplians paru, tidal volume yang kecil, bertambahnya ruang rugi fisiologis, bertambahnya kerja pernafasan, tidak cukupnya ventilasi alveoli, akan menghasilkan hiperkarbia. ${ }^{2,4,7,9,10}$ Pada hipoksemia yang berat akan terjadi metabolisme anaerobik dengan akibat terjadinya metabolisme asidosis yang menyebabkan atelektasis difus, disertai dengan pembentukkan membran hialin. Atelektasis ini dapat menyebabkan tahanan dan tekanan pembuluh darah paru meningkat serta terjadi hipertensi pulmonal, yang terjadi karena vasokonstriksi paru dan diperburuk oleh hipoksia serta bertambahnya pirau dari kanan ke kiri. ${ }^{1-12}$

Keadaan berat dan fatal akan timbul bila terjadi hipertensi pulmonal persisten (HPP). Pada PMH hal ini biasanya berhubungan dengan tekanan paru yang tinggi dan aliran darah paru yang berkurang selama 3 hari sesudah lahir. ${ }^{20} \mathrm{Hal}$ ini menunjukkan bahwa HPP mempunyai kontribusi pada angka kematian $\mathrm{PMH}$ pada bayi kurang bulan. ${ }^{3,20}$ Hipertensi pulmonal persisten atau disebut juga persistent fetal circulation (PFC) dapat terjadi akibat peningkatan resistensi pembuluh darah paru dan akan menyebabkan disfungsi jantung. Bila afterload ventrikel kanan meningkat, tekanan diastolik akhir ventrikel kanan dan tekanan atrium kanan akan meningkat melebihi tekanan di atrium kiri sehingga darah akan mengalir dari kanan ke kiri melalui foramen ovale. ${ }^{2-4,6,18,21}$

Manifestasi klinis yang timbul pada HPP biasanya terlihat 6-12 jam sesudah lahir berupa sianosis ringan sampai berat, kesulitan bernafas, takipnu disertai retraksi dan grunting. Sianosis yang patognomonik pada HPP adalah sianosis diferensial. Pada auskultasi bisa didapatkan impuls ventrikel kanan yang meningkat, suara jantung ke-dua tunggal dan mengeras, irama galop serta soft regurgitan murmur sistolik. 3,18,20-22 Gambaran radiologis yang sering dijumpai adalah penonjolan segmen main pulmonary artery, kardiomegali ringan, sedangkan EKG pada HPP menunjukkan deviasi ke kanan serta hipertrofi ventrikel kanan, hipertrofi ventrikel kiri dan atrium kiri, dan iskemia miokard . ${ }^{2,3,18,20}$ Ekokardiogram dapat memastikan diagnosis dengan ditemukannya struktur jantung normal dengan duktus arteriosus terbuka, foramen ovale, pelebaran ventrikel kanan dan arteri pulmonalis. Pirau kanan ke kiri dapat dipastikan dengan pemeriksaan doppler. Pada pemeriksaan M- mode ekokardiografi kasus HPP, akan didapatkan waktu ejeksi sistolik kedua ventrikel meningkat (RPEP/ RVET > 0,50; LPEP/LVET > 0,38)..$^{2,8,18,23-25}$ Cadangan jantung pada neonatus kurang bulan masih terbatas, maka akan menyebabkan gangguan faal jantung, baik sistolik maupun diastolik. Aliran darah ke paru berkurang dengan salah satu konsekuensinya aliran balik ke atrium kiri akan menurun, maka pengisian ventrikel kiri pada bayi PMH akan menurun. ${ }^{1,2,4,7,10,26}$ Beberapa parameter yang digunakan untuk mengetahui faal diastolik ventrikel kiri dan kanan adalah mengukur nilai puncak gelombang $\mathrm{E}$ dan puncak gelombang A, rasio E/A pada pemeriksaan doppler. ${ }^{2,23-}$ 25,26,27 Untuk mengetahui faal sistolik ventrikel kiri yaitu dengan mengukur periode pra-ejeksi, waktu ejeksi ventrikel kiri, rasio periode pra ejeksi/waktu ejeksi ventrikel kiri. ${ }^{2}$ Disfungsi ventrikel terkait pula dengan perubahan kemampuan miokardium. Dari titik pandang jantung sebagai otot, fungsi miokardium bervariasi memanjang dan memendek melawan beban. ${ }^{2,23}$ Secara efektif hal ini dibagi menjadi diastol, yang selama masa ini otot harus mencapai panjang tertentu dengan pemakaian gaya, serta sistol yang selama masa tersebut terjadi pemendekan yang cukup besar serta pembentukan gaya diperlukan. Adapun faktor - faktor yang mempengaruhi pemendekan serabut adalah preload, after load, dan kontraktilitas. ${ }^{23}$ Pengukuran disfungsi miokard dengan menilai fraksi ejeksi yaitu persentase pemendekan serabut sistolik yang secara klinik dinilai sebagai persentase perubahan volume. ${ }^{23}$

Nilai rerata puncak E pada bayi dengan $\mathrm{PMH}$ ringan berbeda kurang dari $2 \mathrm{~cm} /$ detik dibandingkan bayi tanpa PMH, yang secara statistik tidak berbeda bermakna, dan puncak gelombang $\mathrm{E}$ ventrikel kanan lebih rendah dibandingkan dengan puncak gelombang A. ${ }^{2}$ Puncak gelombang E ventrikel kiri lebih tinggi daripada puncak gelombang $\mathrm{A}$, sedangkan rasio E/A ventrikel kiri pada neonatus kurang bulan dengan PMH tidak menunjukkan perbedaan yang bermakna. ${ }^{2}$ Interval waktu sistolik ventrikel kiri pada neonatus kurang bulan dengan $\mathrm{PMH}$ berbeda secara nyata dibandingkan dengan bayi tanpa $\mathrm{PMH}$, yaitu lebih panjang. Demikian juga waktu ejeksi ventrikel kiri pada bayi dengan PMH ternyata lebih pendek dibandingkan bayi tanpa PMH. ${ }^{2,26}$

Dengan bertambahnya harapan hidup bayi-bayi berat lahir rendah, terlihat pula peningkatan jumlah bayi-bayi dengan DAP. ${ }^{1-4,5,7,9}$ Duktus arterio persisten 
merupakan penyakit jantung bawaan non sianotik yang sering ditemukan pada PJB (5-10\%), 2,28-29 DAP adalah kanal besar yang menghubungkan pangkal arteri pulmonalis dengan aorta desendens. ${ }^{29-35}$ Secara fungsional duktus arteriosus menutup pada $10-15$ jam setelah lahir. ${ }^{29-33}$ Penutupan permanen terjadi pada usia 2-3 minggu. Bila terjadi hipoksia maka tahanan arteri pulmonalis meningkat sehingga terjadi aliran pirau berbalik dari arteri pulmonalis ke aorta melalui duktus arteriosus. ${ }^{2,4,9}$ Biasanya pada 2 atau 3 hari pertama perjalanan penyakit $\mathrm{PMH}$, tahanan vaskular masih tinggi sehingga belum didapatkan pirau kiri ke kanan yang berarti. ${ }^{2-4,18,20,36}$ Dengan perbaikan $\mathrm{PMH}$, tahanan vaskular paru menurun sehingga terdapat perbedaan tekanan yang bermakna antara aorta dan arteri pulmonalis, terjadilah pirau dari kiri ke kanan yang besar. ${ }^{2-4,33,37,38}$ Diagnosis DAP bisa ditegakkan dengan pemeriksaan klinis serial, serta ekokardiografi. ${ }^{2-}$ 4,30-34 Pada pemeriksaan awal bisa didapatkan apneic spells, atau episodes bradycardi. Didapati frekuensi nafas $>70 \mathrm{x} /$ menit, dan hepatomegali $>3 \mathrm{~cm}$. Pada palpasi didapati impuls ventrikel kiri yang hiperdinamik, tekanan nadi $>35 \mathrm{~mm} \mathrm{Hg}$, bounding pulse $>9$ jam pada tekanan udara positif yang kontinyu. Bunyi murmur kontinyu yang klasik merupakan diagnostik, tetapi bunyi murmur yang terdengar biasanya hanya murmur sistolik..$^{2-4,18,20}$ Pada pemeriksaan radiografi didapatkan pletora paru disertai dengan kardiomegali sedang atau berat. Pada pemeriksaan ekokardiografi M-mode didapati rasio LA : Ao $>1,5$ dan pada pemeriksaan ekokardiogram 2D memperlihatkan duktus yang terbuka, diameter dan panjang duktus baik dari parasternal maupun suprasternal. DAP kecil biasanya tidak memberikan gejala. ${ }^{3,4,30-32}$ Tekanan darah dan tekanan nadi dalam batas normal. Kadang teraba getaran bising kontinyu di daerah subklavia kiri. Pada DAP besar, sudah menunjukkan gejala berat sejak minggu-minggu pertama kehidupan. Pada auskultasi terdengar bising kontinyu, bising mid-diastolik terdengar di apeks karena aliran darah berlebihan melalui katup mitral (stenosis mitral relatif). ${ }^{18,20,30}$ Bunyi jantung II tunggal dan keras, dan mudah terjadi gagal jantung. ${ }^{28,32}$ Bayi prematur memiliki angka kejadian yang tinggi terhadap kejadian DAP, dan hal ini sebanding dengan berat lahir. ${ }^{1-4,20,28,33-39}$ Sepertiga dari penderita DAP mempunyai usia kelahiran $<36$ minggu. ${ }^{3}$ Bayi yang lahir dengan berat $<2000$ gram, $36 \%$ menderita DAP dan bayi yang lahir dengan berat > 2000 gram sekitar $12 \% .{ }^{16}$ Suatu studi kolaboratif pada bayi prematur dengan DAP mendapatkan 21\% bayi dengan berat lahir 1750 gram, 9\% bayi dengan berat $<1500$ gram dan $40 \%$ bayi dengan berat $<1000$ gram. ${ }^{3}$ Dalam studi lain, dari 1700 bayi dengan berat lahir di bawah 1750 gram, DAP dengan hemodinamik yang bermakna didapatkan $42 \%$ pada bayi dengan berat lahir 1000 gram, 21\% pada bayi dengan berat 1000 - 1500 gram; dan hanya $7 \%$ bayi dengan berat lahir 1500-1750 gram. .,4,29,31 Angka kejadian lebih tinggi pada bayi-bayi yang lahir dan bertempat tinggal di daerah pegunungan daripada di daerah dataran rendah. ${ }^{2}$ Manifestasi klinis DAP tergantung dari besar atau kecilnya DAP. ${ }^{29-32}$ Pemeriksaan penunjang yang diperlukan adalah foto dada, elektrokardiografi dan ekokardiogram. ${ }^{1,2,4,7,10}$ Tata laksana DAP dengan terapi medikal ataupun pembedahan. ${ }^{1,2,4,7,10}$ Prognosis pada bayi prematur tergantung pada keadaan besar atau kecilnya pirau pada DAP, komplikasi, ataupun faktor penyulit. ${ }^{28-30,35}$ Prognosis pada bayi cukup bulan biasanya sangat baik. ${ }^{3}$

\section{Pemeriksaan Penunjang}

Untuk mendiagnosis keterlibatan kardiovaskular serta $\mathrm{PMH}$ yang mendasarinya, selain berdasarkan gejala klinis, diperlukan beberapa pemeriksaan penunjang seperti laboratorium, foto dada, elektrokardiografi, ekokardiografi, angiokardiografi. ${ }^{1-12}$ Pemeriksaan penunjang dengan foto dada masih merupakan prosedur yang amat penting dalam mendiagnosis kelainan kardiovaskular. ${ }^{1-12,36}$ Keunggulan ekokardiografi dalam mendiagnosis kelainan jantung adalah kemampuan dalam memberi informasi mengenai status perikardium, miokardium, endokardium dan katup jantung. Doppler berguna untuk menegakkan kelainan struktur jantung dan pembuluh darah, menetapkan atau memperkirakan derajat kelainan katup dan hemodinamik, dan menilai keterlibatan kardiovaskular karena penyakit lain. ${ }^{23-25,33}$ Pemeriksaan laboratorium dilakukan dengan pemeriksaan analisis gas darah. Pada pemeriksaan kimia darah akibat adanya asidosis metabolik pada bayi akan terlihat peninggian asam laktat dan asam organik lain. . $2,4,7,9,10$ Tinggi rendahnya asam laktat tergantung dari berat ringannya penyakit. Bila kadarnya lebih dari $45 \mathrm{mg} / \mathrm{dl}$, maka prognosis penyakit akan buruk. Pada pemeriksaan darah juga akan ditemukan pula tanda asidosis metabolik lain seperti merendahnya bikarbonat, 
adanya defisit basa dan penurunan $\mathrm{pH}$. Gambaran $\mathrm{pH}$ darah bisa digunakan untuk menentukan prognosis bayi. Bila $\mathrm{pH}$ darah menetap di bawah 7,2 untuk beberapa jam menandakan adanya proses asidosis yang berat dan biasanya prognosis penyakit buruk. $\mathrm{PaO}_{2}$ akan menurun sampai kurang dari $50 \mathrm{mmHg}$, dengan $\mathrm{FiO} 2$ dari $50 \mathrm{mmHg}, \mathrm{PCO}_{2}$ lebih dari $60 \mathrm{mmHg}$. ${ }^{2,410}$

Tata laksana kelainan kardiovaskular pada SGNN dengan pemberian obat-obatan yang dipergunakan untuk memperbaiki faal miokardium yaitu agonis beta dan digoksin. ${ }^{2}$ Pemberian dobutamin pada bayi dengan $\mathrm{PMH}$ ringan akan memperbaiki faal diastolik ventrikel kiri dan kanan, faal sistolik ventrikel kiri. Dobutamin diberikan dengan dosis $10 \mathrm{ug} / \mathrm{kg} / \mathrm{menit}$ selama 30 menit. $^{2}$

Suatu penelitian pada 421 bayi dengan DAP yang bermakna secara hemodinamik, mendapatkan $79 \%$ terjadi penutupan duktus yang permanen dengan pemberian indometasin. Penutupan ini lebih umum terjadi pada bayi dengan berat lahir 1000 gram dan usia kehamilan $>29$ minggu. ${ }^{4}$ Penutupan DAP yang dilakukan dengan implantasi ductus occluder memberi hasil memuaskan, tetapi prosedur ini masih terbatas dilakukan pada pasien yang sudah agak besar, mengingat makin muda usia makin tinggi kesulitan tekniknya, di samping alat yang tersedia masih sangat terbatas. ${ }^{3,18,29-33}$ DAP besar bila tidak diobati bisa berkembang menjadi endokarditis infektif, hipertensi pulmonal. $24,25,34,36$

\section{Ringkasan}

Sindrom gawat nafas neonatus atau penyakit membran hialin adalah keadaan yang sering terjadi pada bayibayi dengan berat lahir rendah. Penyakit membran hialin disebabkan oleh defisiensi surfaktan, yang dapat menyebabkan atelektasis paru, yang akhirnya dapat menyebabkan tahanan dan tekanan pembuluh darah paru meningkat serta terjadi hipertensi pulmonal. Kelainan kardiovaskular pada SGNN dapat berupa gangguan faal ventrikel jantung, baik sistolik maupun diastolik, disfungsi jantung yang terjadi akibat hipertensi pulmonal persisten, serta disfungsi miokard. Pemberian dobutamin pada bayi dengan PMH ringan akan memperbaiki faal diastolik ventrikel kiri dan kanan serta faal sistolik ventrikel kiri. Pada kasus SGNN yang mengalami penyembuhan, DAP merupakan suatu penyulit di kemudian hari. DAP merupakan PJB non sianotik yang sering didapatkan, lebih banyak pada perempuan dibandingkan pada lakilaki. Pirau yang terjadi adalah dari kiri ke kanan. Tata laksana dengan pemberian obat-obatan ataupun pembedahan.

\section{Daftar Pustaka}

1. Monintja HE. Masalah umum sindrom gawat nafas pada neonatus. Dalam: Monintja HE, Aminullah A, Boedjang RF, Amir I, penyunting. Sindrom gawat nafas pada neonatus. Naskah Lengkap Pendidikan Kedokteran Berkelanjutan Ilmu Kesehatan Anak FKUI XXIII. FKUI; 1991 8-9 Juli; Jakarta: Balai Penerbit FKUI, 1991.

2. Sastroasmoro S. Pengaruh dobutamin terhadap faal kardiovaskular dan perjalanan klinis penyakit membran hialin. Disertasi. Jakarta: Program Pasca Sarjana, 1998. h. 1-89.

3. Gomella TL, Cunningham MD, Eyal FG, Zenk KE. Hyalin Membran Disease. Dalam: Lange, penyunting. Neonatology: management, procedures, on call problems, disease and drugs. Connecticut: A Simon and Schuster company, 1999. h. 503-04.

4. Gorbet A. Respiratory disorders in the newborn. Dalam: Cherninck V, Kendig LE, penyunting. Disorders of the respiratory tract in children. Edisi ke 5. Philadelphia: Saunders, 1995. h. 268-81.

5. Mellins RB, Jobe AH. Respiratory Distress of The Newborn Infant. Dalam : Fishman AP, Penyunting. Pulmonary Distress and disorders, Edisi ke-2. USA : Mc Graw Hill Coy, 1988. h. $2251-61$.

6. Tambunan T, Monintja HE, Karyomanggolo WT, Tamaela LA. Gambaran radiologik paru pada bayi baru lahir dengan respiratory distress. Majalah Kedokteran Indonesia 1978;28:109-16.

7. Stoll BJ, Kliegman RM. Noninfectious disorders, penyunting. Dalam : Behrman RE, Kliegman RM, Jenson HB. Nelson textbook of Pediatrics. Edisi ke 16. Philadelphia : Saunders 2000. h. 451-504.

8. Tyrala LA. Respiratory disorders of the newborn infant. Dalam : Schidlow PV, Smith PS, penyunting. A practical guide to pediatric respiratory diseases. Philadelphia : Hanley \& Belfus Inc. h. 127-40.

9. Rigatto $\mathrm{H}$. Control of breathing the neonate and the sudden infant death syndroma. Dalam: Fishman AP, penyunting. Pulmonary disease and disorders. Edisi ke2. Pensylvania: Mc. Graw-Hill Inc, 1988. h. 1363-70 . 
10. Markum HA, Ismael S, Alatas H, Akib A. Buku ajar ilmu kesehatan anak. Jakarta : FKUI, 1991. h. 302-567

11. Cooper PA, Simchowitz ID, Sandler LD, Rothberg AD, Davies VA. Prevalence of hyaline membrane disease in black and white low-birth weight infants. SMJ 1994;84:23-5.

12. Ross $S$, Naeye RL. Racial and environmental influences of fetal lung maturation. Pediatrics 1981;68:790-5.

13. Rabinovitch M. Vascular 'pathology of PPHNS. Dalam: Long WA, penyunting. Fetal and neonatal cardiology. Philadelphia: Saunders, 1990. h. 656-66.

14. Kliegman RM. Primary Pulmonary Hypertension - Persistent Fetal Circuulation (PFC). Dalam: Behrman RE, Kliegman RM, Arvin AM. Nelson Textbook of Pediatrics, Edisi ke-16. Philadelphia: Saunders, 2000. h. 506-8.

15. Perelman RH, Farrel PM. Analysis of causes of neonatal death in the united states with spesific emphasis on fatal hyaline membran disease. Pediatrics 1982; 70: 570-5.

16. Jobe AH. Pulmonary surfactant therapy. Dalam: Wood JJ, penyunting. Drug Therapy 1993;328:861-8.

17. Schwartz RM, Luby AM, Scanton WJ, Kellog RJ. Effect of surfactant of morbidity, mortality, and resource use in newborn infants weighing 500 to $1500 \mathrm{~g}$. The new England Journal of Medicine 1994;1470-80

18. Graven NS, Misenheimer HR, Lackland. Respiratory distress syndrome and the high risk mother. American Journal Disease child 1965;109:489-94.

19. Lee KS, Fidelman, Tseng PI. Kandall SR, Gartner LM. Respiratory distress syndrome of the new born and complications of pregnancy. Pediatrics 1976;58:675-80.

20. Phibbs RH, Ballard RA, Clements JA. Initial clinical trial of Exosure a protein free synthetic surfactant, for the prophylaxis and early treatment of hyaline membran disease. Pediatrics 1991;88:1-9.

21. Palta M, dkk. Mortality and morbidity after availability of surfactant therapy. Arch Pediatr Adolesc. Med 1994; 148:1295-301.

22. Yu VYH, Monintja HE. Pengobatan sindrom gawat nafas neonatal dengan surfaktan Dalam: Yu VYH, Monintja HE, penyunting. Beberapa masalah perawatan intensif neonatus. Jakarta: FKUI, 1997. h. 1-14.

23. Yu VYH, Monintja HE. Hipertensi pulmonal persisten Dalam: Yu VYH, Monintja HE, penyunting. Beberapa masalah perawatan intensif neonatus. Jakarta: FKUI, 1997. h. 39-51.

24. Huhta CJ. Patent ductus arteriosus in the preterm neonate. Dalam: Long AW, penyunting. Fetal and neonatal cardiology. Philadelphia: Saunders, 1990. h. 389-92.

25. Madiyono B. Diagnosis dan tata laksana penyakit jantung bawaan non sianotik pada neonatus. Dalam: Sastroasmoro S, Madiyono B, Putra ST. penyunting. Pengenalan dan tata laksana penyakit jantung bawaan pada neonatus. Jakarta: Balai Penerbit FKUI, 1994. h. 115-26.

26. Sahn DJ, Demaria A, Kisslo J, Weynan A. Recommendations regarding quatitation in M-Mode echocardiography: Results of survey of echocardiographic measurements. Circulation 1978;58:1072-82.

27. Wilson N, Reed K, allen HD, Marx GR, Goldberg SJ. Doppler echocardiography observations of pulmonary and transvular velocity changes after birth and during the early neonatal period. American Heart Journal 1987;113:750-8.

28. Freed MD. Sirkulasi janin dan sirkulasi transisi. Dalam: Sunarto, penyunting. Kardiologi anak Nadas. Edisi ke1. Yogyakarta: Gadjah Mada University Press, 1996. h. 598-608.

29. Yu VYH, Monintja HE. Duktus Arteriosus persisiten pada neonatus (DAP). Dalam: Yu VYH, Monintja HE. Beberapa masalah perawatan intensif neonatus. Jakarta: FKUI 1997. h. 57-67.

30. Park MK. Pediatric cardiology for practitioners. Edisi ke-3. St.Louis: Mosby, 1996. h. 388-394.

31. Emmanoulides GC, Allen DH, Riemenschneider AT, Gutsegell HP. Patent ductus arteriosus. Dalam: Emmanoulides GC, Allen DH, Riemenschneider AT, Gutsegell HP. Clinical synopsis of Moss and Adam's heart disease in infants, children and adolescents. Philadelphia: Williams \& Wilkins, 1998. h. 286-9.

32. Bernstein D. The Cardiovascular system. Dalam: Behrman RE, Kligman RM, Jenson HB, penyunting. Nelson textbook of pediatrics. Edisi ke-16, Philadelphia: Saunders, 2000. h. 1372-73.

33. Ellison CR, Peckham JG, Lang P et al. Evaluation of the preterem infant for patent ductus arteriosus. Pediatrics 1983;71(3):364-72.

34. Fyler DC. Duktus arteriosus paten. Dalam: Sunarto, penyunting. Kardiologi anak Nadas. Edisi ke-1. Yogyakarta: Gadjah Mada University Press, 1996. h. 714.

35. Stromberg D. Patent ductus arteriosus. Dalam: Taeusch HW, Christiansen RO, Buescher ES, penyunting. Pediatric and neonatal tests and procedure. Philadelphia: Saunders, 1996. h. 245-9.

36. Soenoso S, Sastrosubroto S. Dalam: Sastroasmoro S, Madiyono B, penyunting. Buku Ajar Kardiologi Anak. Jakarta: Binarupa Aksara, 1994. h. 215-21.

37. Cloherty JP, Stark RA. Manual neonatal care. Edisi ke- 
4. Philadelphia: Williams\& Wilkin, 1998. h. 428-46.

38. Park MK. Pediatric cardiology for practitioners. Edisike 3. St.Louis: Mosby, 1996. h. 142-5.

39. Wilson N, Reed K, Allen HD, Marx GR, Goldberg SJ.
Doppler echocardiography observations of pulmonary and transvalvular velocity changes after birth and during the early neonatal period. American Heart Journal 1987;113:750-8. 